\title{
New Product Announcements as Market Signals A content analysis in the DRAM chip industry
}

\author{
Wybe T. Popma, Eric Waarts, Berend Wierenga
}

\begin{tabular}{|l|l|}
\hline \multicolumn{2}{|l|}{ ERIM REPORT SERIES RESEARCH IN MANAGEMENT } \\
\hline ERIM Report Series reference number & ERS-2003-025-MKT \\
\hline Publication & April 2003 \\
\hline Number of pages & 34 \\
\hline Email address corresponding author & wpopma@fbk.eur.nl \\
\hline URL & http://hdl.handle.net/1765/328 \\
\hline Address & Erasmus Research Institute of Management (ERIM) \\
& Rotterdam School of Management / Faculteit Bedrijfskunde \\
& Rotterdam School of Economics / Faculteit Economische \\
& Wetenschappen \\
& Erasmus Universiteit Rotterdam \\
& P.O. Box 1738 \\
& 3000 DR Rotterdam, The Netherlands \\
& Phone: +31 10 408 1182 \\
& Fax: +31 10 408 9640 \\
& Email: info@erim.eur.nl \\
& Internet: $\quad$ www.erim.eur.nl \\
\hline
\end{tabular}

Bibliographic data and classifications of all the ERIM reports are also available on the ERIM website: www.erim.eur.nl 


\section{ERASMUS RESEARCH INSTITUTE OF MANAGEMENT}

REPORT SERIES

RESEARCH IN MANAGEMENT

\begin{tabular}{|c|c|c|}
\hline \multicolumn{3}{|c|}{ BIBLIOGRAPHIC DATA AND CLASSIFICATIONS } \\
\hline Abstract & \multicolumn{2}{|c|}{$\begin{array}{l}\text { New-product announcements (NPAs) have considerable effects on competitors in industrial } \\
\text { markets. Several studies have shown that the perceived threat caused by an NPA may trigger } \\
\text { severe competitive reactions. Yet it is still unclear how the perception of threat by competitors is } \\
\text { related to the specific content of the announcement. } \\
\text { In this study we explore the actual content of NPAs observed in a particular market. We do this } \\
\text { through a multi-year content analysis of new-product announcements in the DRAM memory chip } \\
\text { industry. We analyze patterns in the occurrence of attributes and demonstrate how firm strategy } \\
\text { affects NPA content. Findings from this study provide important insights for managers about the } \\
\text { design of NPAs. It also triggers further research on the use of NPAs in competitive industrial } \\
\text { markets. }\end{array}$} \\
\hline \multirow{3}{*}{$\begin{array}{l}\text { Library of Congress } \\
\text { Classification } \\
\text { (LCC) }\end{array}$} & $5001-6182$ & Business \\
\hline & $5410-5417.5$ & Marketing \\
\hline & HF 5415.15+ & Product management \\
\hline \multirow{3}{*}{$\begin{array}{l}\text { Journal of Economic } \\
\text { Literature } \\
\text { (JEL) }\end{array}$} & M & Business Administration and Business Economics \\
\hline & $\begin{array}{l}\text { M } 31 \\
\text { C } 44\end{array}$ & $\begin{array}{l}\text { Marketing } \\
\text { Statistical Decision Theory }\end{array}$ \\
\hline & $\begin{array}{l}\mathrm{L} 11 \\
\mathrm{M} 11\end{array}$ & $\begin{array}{l}\text { Production, pricing and market structure } \\
\text { Production management }\end{array}$ \\
\hline \multirow{4}{*}{$\begin{array}{l}\text { European Business Schools } \\
\text { Library Group } \\
\text { (EBSLG) }\end{array}$} & $85 \mathrm{~A}$ & Business General \\
\hline & $280 \mathrm{G}$ & Managing the marketing function \\
\hline & $255 \mathrm{~A}$ & Decision theory (general) \\
\hline & $260 \mathrm{~N}$ & Production planning \\
\hline \multicolumn{3}{|c|}{ Gemeenschappelijke Onderwerpsontsluiting (GOO) } \\
\hline \multirow[t]{4}{*}{ Classification GOO } & 85.00 & Bedrijfskunde, Organisatiekunde: algemeen \\
\hline & 85.40 & Marketing \\
\hline & 85.03 & Methoden en technieken, operations research \\
\hline & 85.35 & Productiemanagement \\
\hline \multirow[t]{3}{*}{ Keywords GOO } & \multicolumn{2}{|c|}{ Bedrijfskunde / Bedrijfseconomie } \\
\hline & \multicolumn{2}{|c|}{ Marketing / Besliskunde } \\
\hline & \multicolumn{2}{|c|}{ Concurrentie, productvernieuwing, halfgeleiders } \\
\hline Free keywords & \multicolumn{2}{|c|}{ Competition, innovation, new product announcement, market signals, semiconductors } \\
\hline
\end{tabular}




\title{
New Product Announcements as Market Signals; A content analysis in the DRAM chip industry
}

\author{
Wybe T. Popma \\ Eric Waarts \\ Berend Wierenga
}

March 2003

Correspondence address: Ir. W.T. Popma, Erasmus University, Rotterdam School of Management, Room F1-68, PO Box 1738, 3000DR Rotterdam, The Netherlands. Email: wpopma@ fbk.eur.nl 


\title{
New Product Announcements as Market Signals; A content analysis in the DRAM chip industry
}

\begin{abstract}
New-product announcements (NPAs) have considerable effects on competitors in industrial markets. Several studies have shown that the perceived threat caused by an NPA may trigger severe competitive reactions. Yet it is still unclear how the perception of threat by competitors is related to the specific content of the announcement.

In this study we explore the actual content of NPAs observed in a particular market. We do this through a multi-year content analysis of new-product announcements in the DRAM memory chip industry. We analyze patterns in the occurrence of attributes and demonstrate how firm strategy affects NPA content. Findings from this study provide important insights for managers about the design of NPAs. It also triggers further research on the use of NPAs in competitive industrial markets.
\end{abstract}

\section{Introduction}

Announcing products ahead of market launch is common practice in many industries. Products as diverse as automobiles, movies, software and detergents are usually announced before actual market introduction. New-product announcements (NPAs) are used to inform and thereby influence stakeholders in the market. Advantages of preannouncing include: build-up of customer base [17], keeping potential customers from buying competitive products [1,6], securing distribution channels [26], securing supplier support [21], and satisfying the information needs of 
financial analysts [12]. There are many examples of how (early) announcement of a new product can enhance a successful product introduction. Consider, for instance, the Microsoft XBox game console. It was announced 18 months ahead of its market introduction in 2001. This early announcement was intended to ensure software support for the new console. Game consoles sales and profits are known to be highly reliant on the availability of popular games for a specific system. The early announcement of the XBox caused widespread media attention to the new product, specifically in comparison to the Playstation 2 game console of competitor Sony. Even after Sony introduced the PS2 console at the end of 2000, many consumers hesitated to buy one while waiting for the introduction of the $\mathrm{XBox}$ one year later. In the 18 months between announcement and introduction Microsoft was able to secure various distribution channels for its first game console product. Presales were organized on the Internet in cooperation with Amazon. The build up of customer demand for the XBox before its launch resulted in sales of 1.5 million consoles during the first six weeks after introduction in the US market.

Of course, there are also downsides to the use of NPAs. One of the main disadvantages of preannouncing is that the NPA provides competitors early information about the new product. Based on this information rivals can prepare competitive reactions. Also, potential customers may adapt their buying plans. The possible negative effects of preannouncements in the form of competitive reactions and disruption of customer demand can be illustrated with the example of the announcement of the Palm m500 PDA. In March 2001, Handspring, Palm's main competitor in the Personal Digital Assistant (PDA) market, announced the Handspring Visor Edge. Palm, as the market leader, feared for its innovative reputation and responded by preannouncing (ahead of plan) the Palm m500 one week later, months before actual introduction. In the period between the announcement of the m500 and its market introduction demand for the existing high-end model, 
the Palm Vx, dropped dramatically. Consumers stopped buying the "old" Palm Vx in anticipation of the new m500. Distributors were left with oversupplies of the old product. Prices of the Palm Vx had to be cut. This in turn resulted in a price war with Handspring. The early announcement of the m500 in combination with a general slowing of demand in the PDA market had catastrophic results. Both Palm and Handspring reported losses as a result of the price wars. Both firms lost over $80 \%$ of their stock market value in the following six months. Palm's (unit) market share $^{1}$ shrank from $71 \%$ to $58 \%$ during 2001.

\section{Purpose of this study}

The potential positive and negative effects of NPAs imply that from a managerial point of view it is important to carefully decide on the use of NPAs and to assess how the content of new-product announcements may influence perceptions of competitors and subsequent reactions in the market. Correspondingly, the aim of the current study is to explore in-depth the use and content of actual new-product announcements in a particular market, in this study the DRAM chip market. This provides us with new information about the various ways of use of NPAs and content styles that are used in practice. It also provides the basis for research regarding the effect of NPA content on the perception of, and competitive reaction to, new-product announcements.

\section{Literature}

Within the field of marketing strategy research, competitive behavior, the aggregate of actions and reactions of competitors, plays a central role [24]. The interdependence of competitors within an industry implies that the outcome of an action initiated by one firm will be contingent on the

\footnotetext{
${ }^{1}$ Source: NPD Intellect.
} 
reaction of rival firms. Literature in the field of marketing has recognized that both actions and announcements can influence competitive behavior [18]. Earlier research has identified market signals $[20,8]$ as instruments that influence competitive behavior.

We define a New-Product Announcement (NPA) as:

"a formal and deliberate communication by a firm regarding the prospective market-introduction of a new product by this firm".

Thus NPAs represent market signals to competitors. But how do NPA attributes (such as marketing mix information mentioned in the announcement) influence the evaluation of the NPA by competitors? Since the inclusion of newsrooms with (archived) NPAs on corporate websites is becoming standard practice, it is easier than ever for rival firms to collect and analyze each other's product announcements. As a consequence NPAs play a bigger role in competitive interaction than before. Research shows that the competitive reactions to NPAs depends on the evaluation of the announcement in terms of, among other things, credibility, commitment, consistency, consequences, and threat $[22,9,10]$. Ultimately it is vital to know how such perceptions are linked to the content of the announcement itself. Consider the following NPA from Apple ${ }^{2}$ :

\footnotetext{
"Apple today announced Shake 2.5, the industry-leading compositing and visual effects software which has been used in the production of over a hundred motion pictures including the past five winners of the Academy Award for Best Visual Effects: Lord of the Rings: The
}

\footnotetext{
${ }^{2}$ Source: Announcement on the Apple newsroom website, July 22, 2002 http://www.apple.com/pr/library/2002/jul/22shake.html
} 
Fellowship of the Ring, Gladiator, The Matrix, What Dreams May Come and Titanic. (...) "Shake is deployed facility-wide as the primary compositing software at Weta Digital" said Scott Houston, Weta Digital's CTO and long-standing Shake customer. "We couldn't have done Lord of the Rings: The Fellowship of the Ring, without it.” (...) Shake 2.5 is scheduled to be available in August (...) for a suggested retail price of $\$ 4.950$ with annual maintenance of \$1.199."

Reading the above NPA, one wonders, what effects do attributes such as endorsement or testimonials ("We couldn't do without it") or the mentioning of a timeframe for launch ("available in August") have on the threat perception that a competitor experiences from this announcement? Does inclusion of a timeframe for launch and a specific price ("retail price of $\$ 4.950 ")$ increase credibility of the announcement? What effect does perceived credibility of the announcement have on threat perception? These and other questions can only be answered after we have a clear picture of the nature of NPA content with regard to marketing mix elements that play a role in competitive interaction.

To put this in a research framework, we use the classical Brunswik Lens model [3], where the observer uses objective cues to form a perception of the actual event behind those cues. Cues can be related to the appearance of the announcement (aspects such as lay-out of the announcement, letter type, inclusion of pictures) and the content of the announcement (for instance the inclusion of specific information) In this case, the competitor uses the content of the NPA (the attributes mentioned in the announcement) to form a perception of the threat that the event (the product introduction as announced) represents. Figure 1 depicts the cognitive process leading to competitive reaction where the lens model (left-hand side) is combined with a competitive response model (right-hand side, cf. [25,22,14]).

- Figure 1 about here - 
The model reads as follows. Initially, in phase I, the competitor is confronted with the announcement. Next, in phase II, the competitor reads the content of the NPA and a perception of threat is formed in phase III. Based on the content of the NPA a threat perception is formed on the basis of the perceived consequences [9], perceived credibility [22], perceived commitment and perceived consistency [7] of the NPA message. On the basis of the threat perception the competitor decides about a possible competitive reaction in phase IV. In the literature phases I, III and IV have received attention, addressing the relationship between perception of a newproduct introduction and the subsequent competitive reaction. Phase II, the actual content of an NPA is the focus of the present study. Relevant content attribute types that are expected in newproduct announcements are, along the lines of the marketing mix, product specifics [14], price specifics [18], promotion specifics [5], distribution specifics [11,4] and market specifics [14].

In the current research we analyze which of these attributes actually appear in new-product announcements and to what extent. The first research question is:

Question 1: Which attributes relevant to competitive interaction are present in NPA messages and with what frequency?

Next we want to know whether it is possible to distinguish patterns in the occurrence of attributes in new-product announcements. Are firms distinct in their use of attributes in NPAs or can NPAs be regarded as homogenous in terms of content within a specific industry? From a competitive interaction perspective, is NPA content related to the strategic stance of the announcing firm? 
This would provide further evidence of the strategic role of NPAs in competitive interaction [4]. The second research question is therefore:

Question 2: Is the frequency of attribute occurrence in NPAs company-specific and can attribute occurrence in NPAs be related to the strategic stance of the firm?

The research questions will be answered by analyzing the content of announcements in a particular industry, i.e. the DRAM chip industry, where NPAs occur on a regular basis.

\section{Methodology}

In order to provide a quantitative overview of NPA attribute occurrence, and to check whether attribute-occurrence is announcer-specific, we choose content analysis as a methodological means to our objectives. We base our analysis on the classic approach of Berelson [2], who distinguishes four purposes for content analysis: description of content, inferring announcer characteristics, inferring audience characteristics and finally determining message effect on the audience. The first purpose is description of characteristics of message content. In our research we analyze the occurrence of specific attributes that can be distinguished in the NPAs. To our knowledge this is the first study to provide a systematic inventory of NPA content. The second purpose is to make inferences about the producers of NPA messages. We will address this by analyzing whether the strategic stance of an announcing firm can be linked to the occurrence of specific attributes in its NPAs. Furthermore, the content analysis of announcements made by all major firms in one industry can show whether NPA content can be regarded as company specific 
or as homogeneous within one industry. The third purpose of content analysis is to make inferences about audiences of the NPAs. By looking at the possible audiences of new-product announcements and linking these to specific attributes found in the announcements we can make inferences about the audiences of the NPAs. Because our research focuses on the public of competitors, we specifically focus on attributes that may have an impact on the evaluation of NPAs from a competitive viewpoint. The final purpose of content analysis, as distinguished by Berelson, is to determine the effect of content on the audience. Although we will not address this issue in the present paper, the NPA attributes found in our research will be of use in further research on the perception (based on announcement attributes) of new-product announcements by specific publics, in our case, industry competitors.

\section{Attributes}

Based on the literature on competitive interaction during product announcement and product introductions we selected five groups of attribute types that are of importance through the competitive interaction decision-making process. These include attributes related to the marketing mix [5]: product, price, promotion and distribution (see also Table 2). Product attributes, inherent product characteristics as mentioned in the announcement, are relatively specific to product category and industry. Price attributes include inherent price-related characteristics of the new product such as the specific price and the competitiveness of the price in relation to existing rival products. Promotion attributes include the announcement of promotion campaigns related to the new product, use of a spokesperson in the announcement and use of external endorsement. Distribution attributes include the mentioning of distributions channels for the new product, but also attributes related to introduction timing $[11,4,16]$. As a 
fifth group of NPA attributes we study market-related characteristics such as market growth and competitive market position [14].

Next, using the classification of Kotler [13] we distinguish different strategic stance types of announcing firms, based on their market strategies. The first type is the market leader, its position characterized by the largest market share, frequent introduction of new products and steady growth of sales. A market leader generally tries to expand the total market (since it will benefit most, having the largest market share), and defend and expand its market share.

The second type is the market challenger. This firm is characterized by an aggressive stance, trying to beat the market leader through competition on aspects such as price, product, manufacturing costs, promotion and distribution. The third type is the follower. Its market share is relatively stable, it imitates the products of the market leader and is generally characterized by low ROI. The fourth type is the market nicher. Firms in this category play a leading role in a specific niche of the overall market.

\section{Industry and data}

In order to perform a thorough analysis of new-product announcements a number of requirements must be met. First, it is important to analyze the original announcements if we want to make inferences about the producers of NPA message. New-product announcements will often appear in the (trade) press, but at that stage other parties than the announcing firm may have edited the announcement before publication. It is therefore preferable to use NPAs that originate directly from the announcing firm. Secondly, in order to get an integral view it is important to analyze a (preferably large) number of announcements over a certain period of time. To be able to compare the NPAs, it is necessary to look at announcements of homogeneous products, preferably within one branch of industry. 
We were able to fulfill these requirements by looking at NPAs in the worldwide DRAM memory chip industry. This industry is characterized by a limited number of players (the ten largest firms have a combined world market share of 94\%), frequent product introductions and consequently also frequent product announcements (a total of 64 NPAs were collected over a two-year period). Another advantage of the DRAM chip industry is the early adoption of the Internet as an information medium. All ten firms analyzed had corporate websites with "newsrooms" where NPAs are published and archived. Of the ten largest producers we tracked all NPAs made public via their corporate websites during the years 1999-2000 (see Table 1). We chose to analyze this period because it showed a relatively large number of product introductions and NPAs available through the corporate websites. This period was characterized by ongoing consolidation in suppliers, strong growth in demand for DRAM chips for PCs and mobile phones in 1999 and the first half of 2000, followed by declining demand in the second half of 2000 .

\section{- Table 1 about here -}

Typical characteristics of the DRAM industry are the worldwide scope of the market, the high speed of innovation, the frequency of new-product introductions and the relatively high level of competitive pressure. The DRAM industry is further characterized by high levels of fixed costs for production technology. Competition is based on product characteristics such as power-use, speed and performance. Product pricing plays a special role because new innovative chips can command premium prices on the market, whereas existing chip designs quickly become standard commodities as the production technology becomes more widely available over time. Typical are the very high levels of investment in production technology (a new chip factory will normally cost upwards of 1 billion euro to build). The high level of investment needed for production is 
one of the main reasons for consolidation in the industry in recent years. Economies of scale can cause brutal price wars specifically for the commodity DRAM chips that are produced by several competitors.

The DRAM market can be divided in three types of firms, based on their market position and strategies. Samsung is the market leader, its position characterized by the largest market share, frequent introduction of new products and steady growth of sales. Samsung is also known in the industry for its innovative capacities in DRAM research and development (R\&D). The second and third largest companies (Micron and Hyundai) can be classified as "challengers". High sales growth, large market shares and frequent new product introductions characterize their market positions. Both firms are also recognized in industry publications as possible threats to the dominant position that Samsung has had in the industry for a number of years. Hyundai is strong in high volume production. Micron on the other hand is known as the cost leader, known for its ability to trim manufacturing costs to the minimum. The last seven companies in Table 1 can be characterized as "followers"; firms with relatively stable market shares, less frequent product introductions and although sometimes strong in certain niches not recognized as leading in the general DRAM market. It is difficult to make a distinction between followers and nichers in the DRAM market. Among the firms we might characterize as followers firms that play a "nicher" role in some parts of the DRAM market (for instance offering DRAMs specifically for mobile phones), however all these firms also offered "commodity" DRAM chips. We therefore chose to distinguish only three categories: "leader", "challenger" and "follower" (cf. [19]). 


\section{Findings}

\subsection{Occurrence of NPA attributes}

As already mentioned, a total of 64 new-product announcements were observed from the corporate websites in the two-year period 1999-2000. The length of the announcement averaged 460 words, ranging from 170 to 1054 words. To answer our first research question as to the frequency of attributes mentioned in NPAs, all NPAs were coded for the occurrence of attributes related to the marketing mix (see Table 2).

- Table 2 about here -

As can been seen from Table 2 the content analysis showed a large variation in the attributes mentioned in the NPAs, ranging from $86 \%$ mentioning the time to market sampling to no mentioning at all of specific promotion or distribution information (for instance promotion campaign arrangement or specific distribution agreements).

Below we will discuss the attribute occurrences in more detail and provide some examples of how NPAs are designed in this industry.

\section{Product-related attributes}

The NPAs in this industry were all clearly product oriented, with often-large parts of the message devoted to product-specific information. It was found that "power" and "speed" of the chips, two essential competitive product characteristics in this industry, were included prominently as product advantage in $72 \%$ and $62 \%$ of the announcements respectively. This provides evidence that new-product announcements, though generally not aimed at competitors [23], can contain 
highly relevant competitive information. This also explains why firms often rely on NPAs when collecting information about competitors [22].

Somewhat surprisingly "memory" as a product advantage was mentioned in only $33 \%$ of the NPAs; it seems that memory capacity is a sine qua non and in general is not specifically mentioned except in the product name ("XYZ-DRAM $128 \mathrm{Mb}$ "). See the example of the Samsung NPA extract in the box below. Other product attributes that occurred in the announcements were compatibility (47\%), performance $(45 \%)$, size $(31 \%)$ and standardsetting $(11 \%)$.

"Samsung is expected to strengthen its position as a major force in the market for next-generation, high-speed memory chips, as the company goes into mass production of $3^{\text {rd }}$ generation Rambus dynamic random access memory (RDRAM) chips. (...) The third-generation RDRAMs being massproduced by Samsung will be available in $128 \mathrm{Mb}, 144 \mathrm{Mb}$ and $288 \mathrm{Mb}$ memory capacities ${ }^{1}$. (...) At the same time, Samsung's next-generation mass-production technology reduces the chip size ${ }^{2}$ and shortens the chip's internal signal processing time. Therefore, operation speed ${ }^{3}$ is improved by over 30 percent and the DRAMs are now capable of reaching speeds of 1,066-MHz, the fastest of any memory chip currently available ${ }^{4}$. (...) Importantly, Intel's Pentium 4 processor chip, slated for its market debut at the end of November, is reportedly going to exclusively use RDRAMs ${ }^{5}$ in the near future. “

- Source: Samsung announcement, November 14, 2000.

Announcements were found to contain references to such product specific attributes as: (1) memory capacity, (2) chip size, (3) operation speed, (4) standardsetting ability and (5) compatibility. 


\section{Price-related attributes}

Specific product prices were mentioned in $45 \%$ of the announcements. Price competitiveness (“...product XYZ will be cheaper than existing solutions on the market”) was mentioned in $42 \%$ of the NPAs. See, for instance, the Hyundai announcement extract below.

“The 2Mx32 166MHz DDR DRAM is available in sample quantities and is priced at $\$ 21.00$. In the $2 Q$ this year, it will be available in volume quantities and priced at $\$ 15.50 . "$

- Source: Hyundai announcement, February 14, 2000.

\section{Promotion related attributes}

Specific promotion information was not given in any of the 64 product announcements. This finding points to the typical business-to-business nature of the DRAM industry. DRAM chips are mainly sold via contracts (in advance) to OEMs, with the remainder going to the spot market. Although product and price specifics are included prominently, promotion arrangements are not mentioned in new-product announcements.

Spokespersons (related to the firm) were used in 59\% of the NPAs. When distinguishing the main spokesperson per announcement it was found that spokespersons from the ranks of topmanagement (vice-president or higher) were used in $31 \%$ of the NPAs. Sales/marketing spokespersons appeared in $27 \%$ of the announcements, R\&D spokespersons in only $2 \%$. The rest of the NPAs $(42 \%)$ contained no specific spokesperson.

In the NPAs, external endorsement took the form of direct quotes by firm-external persons (e.g. industry analysts, see e.g. the Mitsubishi announcement in the box below) or references of 
statements about the new product as made by company outsiders. External endorsement occurred in $23 \%$ of the announcements.

“...Mitsubishi has positioned itself as one of the first DRAM manufacturers to announce the availability of its complete line of PC133 SDRAMs in the 0.18- $\mu \mathrm{m}$ process technology," said Sherry Garber, senior vice president and DRAM analyst at Semico Research.”

- Source: Mitsubishi announcement, June 29, 2000

\section{Distribution related attributes}

Specific mention of distribution channels or distribution strategies was not made in any of the 64 announcements. This again may be related to the business-to-business nature of the DRAM industry. The time-to-market, the time between the publication of the NPA and the availability of the new chip was mentioned prominently in most announcements. One specific element of the introduction of DRAM chips is that there are actually two moments of "market introduction". First limited numbers of chips are made available for "sampling". Customers can design and test compatible hardware and software before the DRAM chips are used in mass production. Only later (one or two months) are the DRAM chips available in volume quantities. The "sampling" time-to-market was mentioned in $86 \%$ of the NPAs. The "mass market" time-to-market was mentioned in $73 \%$ of the announcements (see the Toshiba announcement below).

"Samples are available now and volume production is slated for the fourth quarter of 2000" - Source: Toshiba announcement, July 17, 2000. 


\section{Market-related attributes}

Sometimes expected market growth or intended market position of the new product was mentioned in the NPAs. In $23 \%$ of the announcements market growth was touched upon, intended market position was mentioned in $17 \%$ of the NPAs.

"These developments are forecast to boost the world Rambus DRAM market by some 132\% annually from US\$1.7 billion this year to around US\$9.2 billion by 2002 . Samsung Electronics now holds 53\% of the world RDRAM market. By launching the mass production of the third-generation version, Samsung expects annual sales to reach US\$900 million in 2000."

- Source: Samsung announcement, November 14, 2000.

It can be concluded that product and pricing related attributes were mentioned most often in the announcements. Promotion and distribution got very little attention, except for the element of introduction timing, which was mentioned in most NPAs. These findings can be explained with the business-to-business nature of the memory-chip market; specific promotion schemes are left to the customers (the computer and electronics producers that sell end-products which include the memory chips). It seems that the DRAM chip is regarded as a commodity product that would not benefit from promotion campaigns by the chip-producers directly aimed at the end-user (as for instance Intel did with the famous "Intel Inside" campaign).

Market forecasts are sometimes included in the announcements, in particular so by the market leader Samsung. Next we will try to answer our second research question: whether the inclusion of specific attributes in the announcement is related to the company announcing the new chip and/or the strategy followed by the announcing company. 


\subsection{Firm specific content of NPAs}

Comparing the occurrence of specific NPA attributes per announcement and per firm, it is possible to analyze whether NPA content in terms of the attributes as described before can be regarded as company-specific. Our null-hypothesis is that NPAs do not differ with respect to the sending firm of by type of firm. To analyze this issue statistically, each announcement was represented by a vector consisting of 15 elements (the 17 attributes in table 2 minus the attribute items "promotion" and "distribution" which were both 0 for all 64 NPAs). These 64 vectors form the basis for a proximity matrix where the proximity (d) between two vectors $\mathrm{i}$ and $\mathrm{j}$ based on $\mathrm{t}$ $\in(1,15)$ attributes is defined as

$$
d_{i j}=\sqrt{\sum_{t=1}^{15}\left(x_{i t}-x_{j t}\right)^{2}} \quad \text { with } \mathrm{i} \text { and } \mathrm{j} \in(1,64)
$$

The proximity matrix (binary Euclidian distance) was calculated to analyze the difference in occurrence of NPA attributes per announcement. An independent-samples t-test of variance was conducted to explore whether the inclusion of NPA attributes differs significantly between firms as compared to within firms. Two groups of proximities were distinguished (Group 1: proximities between firms; Group 2: proximities within firms). Results in Table 3 show a statistically significant difference in scores for proximities between firms $(\underline{\mathrm{M}}=2.51, \underline{\mathrm{SD}}=0.49)$, and proximities within firms $[\underline{\mathrm{M}}=2.22 ; \underline{\mathrm{SD}}=0.56 ; \underline{\mathrm{t}}(251.67)=7.51, \underline{\mathrm{p}}=.00]$.

- $\quad$ Table 3 about here - 
As can be seen from Table 3, the within variance of NPAs of most firms is smaller than the overall variance between all NPAs, which indicates that the content of the NPAs is firm specific. In particular Hitachi has a strong own content design of its NPAs, with closer inspection revealing standard paragraphs containing similar information used in announcements of different products.

We also investigated the link between NPA content and the strategic stance of the sending companies. Using the strategic stance typology of Kotler [13], Table 4 shows the occurrence of NPA attributes per strategic stance.

- Table 4 about here -

An independent-samples t-test of variance was conducted to explore whether the inclusion of NPA attributes is significantly related to the strategic orientation of the firm. Each time two groups of proximities were distinguished (Group 1: proximities between announcements by firms in the same strategic stance group; Group 2: proximities between announcements by firms within the group and announcements by firms outside the group), using the same proximity measures as described in the previous section. Results showed a significant difference in scores for proximities of the market-leader versus challengers and followers $(\underline{\mathrm{M}}=2.68, \underline{\mathrm{SD}}=0.40)$, and proximities within the market-leader group $[\underline{\mathrm{M}}=2.52, \underline{\mathrm{SD}}=0.35 ; \underline{\mathrm{t}}(636)=-3.2, \underline{\mathrm{p}}=0.00]$. Also for the challengers a significant difference was found in scores for proximities to leaders and followers $(\underline{\mathrm{M}}=2.46, \underline{\mathrm{SD}}=0.42)$, versus proximities within the challenger group $[\underline{\mathrm{M}}=2,19, \underline{\mathrm{SD}}=$ $0.49 ; \underline{\mathrm{t}}(312.3)=-7.2, \underline{\mathrm{p}}=0.00]$. Finally, for the follower group the scores for proximities to leaders and challengers $(\underline{\mathrm{M}}=2.53, \underline{\mathrm{SD}}=0.41)$, versus the proximities within the follower group $[\underline{\mathrm{M}}=2.37, \underline{\mathrm{SD}}=0.45 ; \underline{\mathrm{t}}(1518)=-7.1, \underline{\mathrm{p}}=0.00]$ showed a significant difference. Hence, it can be 
concluded that NPA content is linked to the strategic stance of the announcing firm. This is an important finding because it shows the relevance that new-product announcements can have for competitive interaction in the marketplace. Below we discuss some of the typical differences one may find between NPAs from leader, challengers and followers in this market. These are summarized in Table 5.

- Table 5 about here-

With regard to product specific attributes we see that the market leader includes the attributes "speed" and "power" in its announcements, though less often than the challengers. Furthermore, "memory", "size" and "standardsetting" are frequently appearing attributes in its NPAs. This has face validity because the market leader in this industry defends its position by constant innovation, producing smaller chips with more memory capacity, in the process of setting the standards. Challengers mention "power" and "speed", two essential competitive product characteristics, more frequently than either the market leader or the followers. Challengers also mention "performance" more often than firms in the other strategic stance types. To emphasize their competitive advantages compared to the market leader, challengers communicate their products in terms of high speed, power, performance, and also the price. Whereas the market leader never mentions specific prices, the challengers and followers include price information in over half of their announcements. Interestingly, the market leader mentions price competitiveness (“...product will be cheaper than...”) significantly more than challengers or followers. Although no specifics are mentioned, the market leader seems to indicate that price is a competitive weapon it is prepared to use to defend its market share [15]. 
With respect to distribution policies, sampling introduction timing information appeared less in announcements made by the market leader in comparison with challengers and followers. All strategic stance types mentioned mass-market introduction timing to comparable extent. It appears that the timing of NPAs is relatively homogeneous within this industry [11].

Finally, information regarding market growth and intended market position of the new product was not included in most NPAs. The market leader mentioned market related attributes significantly more than either challengers or followers. In doing so the market leader typically tries to direct the market and take the lead in market developments [4].

\section{Discussion}

Three major conclusions can be drawn from this study. First of all, it has been shown that the methodology of content analysis is very well suited for the analysis of new-product announcements. It is remarkable that up until now the content of product announcements has not been systematically analyzed in the area of management studies, and in particular marketing. The observed differences between the content of NPAs raise the question whether or not NPAs are set up having the competitor as an audience group in mind. In a highly competitive industry such as the DRAM chip market competitor intelligence can be expected to play an important role. Further research using content analysis and additional methodologies can provide insights into the announcing firms, the targeted audiences and the interaction between them facilitated by the newproduct announcement message.

Secondly, while we observe that the content of new-product announcements varies strongly among firms, we also find that NPAs tend to be company-specific. That is, the announcements 
within one industry are not homogeneous, but their content varies across firms. This is an important finding for several reasons. First, it provides a basis for marketing research that regards NPAs as unique messages that can be analyzed in order to get insight into the behavior and intentions of the announcing firm. Second, it can now be analyzed how NPAs affect competitive interaction, since it was shown that NPAs form unique messages which, based on their content, may change perceptions of rivals and thus provoke competitive reaction.

A third major conclusion from this study is that the strategic stance of announcing firms has an effect on the type of content that can be found in their NPAs. This provides evidence that NPAs from a strategy viewpoint play a role in competitive interaction. A link has thus been found between the announcing firm and the NPA. The next step in research will be to find the link between NPA and receiver. Looking at our model (see Figure 1) we have now focused on phase II, the next step will be to link phases II and III. This can be done by looking at the impact of NPA content on the level of threat that a competitor, confronted with the announcement, perceives.

This study is subject to a number of limitations. First, the new-product announcements used in this study originate from only one industry. It can be expected that the quantity and occurrence of attributes is to some extent industry-specific. Nevertheless it was our aim to perform exploratory research on NPA attributes and as such we were able to gain a number of important insights. Although the specific NPA attributes may differ from industry to industry, the underlying patterns of company- and strategy-specificity have been shown to exist and can be expected to occur in other industries as well. A second limitation concerns the sample size of NPAs. We were able to collect 64 NPAs over a two year time period. A larger sample size can be achieved by including NPAs over a larger time-span. However this brings difficulties in its own right 
because of the current consolidation in the DRAM industry. On the other hand, it would be difficult to find any other industry with relatively homogenous products where this amount of NPAs per year can be found. A third limitation concerns the fact that we only analyzed NPAs published directly by the announcing firm on the Internet. We specifically chose to only study these announcements because they contain only those attributes that are consciously made public by the announcing firm. Further research could focus on analyzing other types of NPAs such as announcements made during trade shows and announcements as published in the trade press. 


\section{References}

[1] Bayus B, Jain S, Rao AG. Truth or consequences: an analysis of vaporware and new product announcement. Journal of Marketing Research 2001;38(1):3-14.

[2] Berelson B. Content analysis in communication research. New York: Hafner, 1952.

[3] Brunswik E. Representative design and probabilistic theory in a functional psychology. Psychological Review 1955;62(3):193-217.

[4] Calantone RJ, Schatzel KE. Strategic foretelling: communication-based antecedents of a firm's propensity to preannounce. Journal of Marketing 2000;64:17-30.

[5] Gatignon H, Anderson E, Helsen K. Competitive Reactions to Market Entry: Explaining Interfirm Differences. Journal of Marketing Research 1989;26(1):44-56.

[6] Greenleaf EA, Lehmann DR. Reasons for substantial delay in consumer decision making. Journal of Consumer Research 1995;22:186-199.

[7] Heil OP, Day GS, Reibstein DJ. Signaling to competitors. In: Day GS, Reibstein DJ, editors. Wharton on dynamic competitive strategy, New York: Wiley, 1997.

[8] Heil OP, Robertson TS. Competitive marketing signals: a research agenda. Strategic Management Journal 1991;12:403-418.

[9] Heil OP, Walters RG. Explaining competitive reactions to new products: an empirical signaling study. Journal of Product Innovation Management 1993;10:53-65.

[10] Hultink EJ, Langerak F. Launch decisions and competitive reactions: an exploratory market signaling study. Journal of Product Innovation Management 2002;19:199-212.

[11] Kohli C. Signaling new product introductions: a framework explaining the timing of preannouncements. Journal of Business Research 1999;46:45-56.

[12] Koku PS, Jagpal HS, Viswanath, PV. The effect of new product announcements and preannouncements on stock price. Journal of Market Focused Management 1997;2:183199.

[13] Kotler P. Marketing Management. London: Prentice-Hall, 2000.

[14] Kuester S, Homburg C, Robertson TS. Retaliatory behavior to new product entry. Journal of Marketing 1999;63(4):90-106.

[15] Krishnamurthi L. Pricing Strategies and Tactics. In: Iacobucci D, editor. Kellogg on Marketing, New York: Wiley, 2001. 
[16] Lilly B, Walters R. Toward a model of new product preannouncement timing. Journal of Product Innovation Management 1997;14:4-20.

[17] Moehrle M. Praemarketing. Gabler, Wiesbaden, 1995.

[18] Moore MC. Signals and choices in competitive interaction: the role of moves and messages. Management Science 1992;18;483-500.

[19] Norwood A. DRAM Vendor Magic Quadrant. Gartner Research Note 2002:M-17-3707 (July).

[20] Porter M. Competitive strategy: techniques for analyzing industries and competitors. New York: The Free Press, 1980.

[21] Robertson TS. How to reduce market penetration cycle times. Sloan Management Review 1993;35:87-95.

[22] Robertson TS, Eliashberg J, Rymon T. New product announcement signals and incumbent reactions. Journal of Marketing 1995;59(3):1-15.

[23] Schatzel KE, Calantone RJ, Droge C. Beyond the firm's initial declaration: are preannouncements of new product introductions and withdrawals alike? Journal of Product Innovation Management 2001;18:82-95.

[24] Varadarajan PR, Yayachandran S. Marketing Strategy: an assessment of the state of the field and outlook. Journal of the Academy of Marketing Science 1999;27(2):120-143.

[25] Waarts E, Wierenga B. Explaining competitors' reactions to new product introductions: the roles of event characteristics, managerial interpretation, and competitive context. Marketing Letters 2000;11(1):67-79.

[26] Wind J, Mahajan V. Marketing hype: a new perspective for new product research and introduction. Journal of Product Innovation Management 1987;4:43-49. 
Figure 1: Conceptual model of New-Product Announcement information processing; Phase II is the focus of this study

\begin{tabular}{|l|l|l|l|}
\hline $\begin{array}{l}\text { Phase I: } \\
\begin{array}{l}\text { Announcement } \\
\text { is noticed }\end{array}\end{array}$ & $\begin{array}{l}\text { Phase II: } \\
\text { Announcement } \\
\text { content is read }\end{array}$ & $\begin{array}{l}\text { Phase III: } \\
\text { Threat perception is formed }\end{array}$ & Phase IV: \\
Decision is made
\end{tabular}

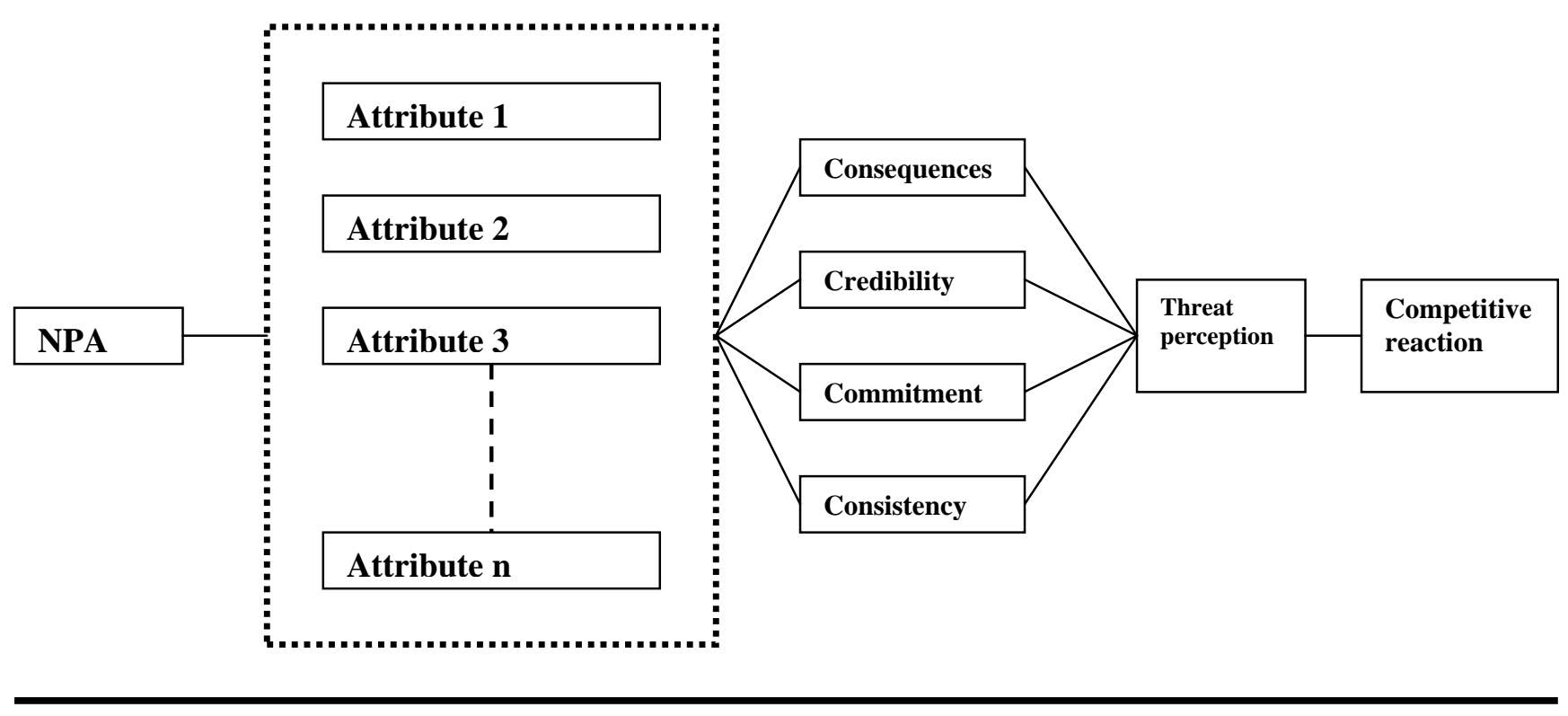


Table 1: Ten largest DRAM producers (source: EBN)

\begin{tabular}{|l|l|l|l|l|l|l|l|}
\hline $\begin{array}{l}\text { Rank } \\
\text { in } \\
2000\end{array}$ & Name & Country & $\begin{array}{l}\text { Sales } \\
1999\left(\begin{array}{l}\text { Sales } \\
\text { billions })\end{array}\right.\end{array}$ & $\begin{array}{l}\text { Market share } \\
\text { billions })\end{array}$ & $\begin{array}{l}\text { Number of } \\
(2000, \text { sales })\end{array}$ & $\begin{array}{l}\text { SRAM NPAs } \\
(1999-2000)\end{array}$ & Stance \\
\hline 1 & Samsung & S-Korea & 4.77 & 6.64 & $23,0 \%$ & 11 & Leader \\
\hline 2 & Micron & USA & 3.33 & 5.96 & $20,6 \%$ & 13 & Challenger \\
\hline 3 & Hyundai & S-Korea & 4.01 & 5.59 & $19,3 \%$ & 8 & Challenger \\
\hline 4 & NEC & Japan & 1.90 & 1.90 & $6,6 \%$ & 6 & Follower \\
\hline 5 & Toshiba & Japan & 1.08 & 1.60 & $5,5 \%$ & 5 & Follower \\
\hline 6 & Infineon & Germany & 1.33 & 1.50 & $5,2 \%$ & 4 & Follower \\
\hline 7 & Hitachi & Japan & 0.47 & 1.30 & $4,5 \%$ & 6 & Follower \\
\hline 8 & Mitsubishi & Japan & 0.87 & 1.00 & $3,5 \%$ & 3 & Follower \\
\hline 9 & Mosel Vitelic & Taiwan & 0.72 & 0.88 & $3,0 \%$ & 4 & Follower \\
\hline 10 & Fujitsu & Japan & 0.54 & 0.67 & $2,3 \%$ & 4 & Follower \\
\hline
\end{tabular}


Table 2. Occurrence of attributes mentioned in NPAs

\begin{tabular}{|l|l|l|}
\hline \multirow{5}{*}{ Product } & Attributes & $\begin{array}{l}\text { Percentage of NPAs in } \\
\text { which this attribute } \\
\text { appears }\end{array}$ \\
\cline { 2 - 2 } & Power & 72 \\
\cline { 2 - 3 } & Speed & 62 \\
\cline { 2 - 3 } & Compatibility & 47 \\
\cline { 2 - 3 } & Performance & 45 \\
\cline { 2 - 3 } & Memory & 33 \\
\cline { 2 - 3 } & Size & 31 \\
\cline { 2 - 3 } & Standardsetting & 11 \\
\hline Price & Specific price & 45 \\
\cline { 2 - 3 } & Price competitiveness & 42 \\
\hline Promotion & Promotion campaigns & 0 \\
\cline { 2 - 3 } & $\begin{array}{l}\text { Identified spokesperson } \\
\text { in NPA }\end{array}$ & 59 \\
\cline { 2 - 3 } & Endorsement in NPA & 23 \\
\hline Distribution & Distribution channels & 0 \\
\cline { 2 - 3 } & $\begin{array}{l}\text { Time to market } \\
\text { sampling }\end{array}$ & 86 \\
\cline { 2 - 3 } & Time to mass market & 73 \\
\hline Market & Expected market growth & 23 \\
\cline { 2 - 3 } & $\begin{array}{l}\text { Intended market } \\
\text { position }\end{array}$ & 17 \\
\hline
\end{tabular}




\section{Table 3: Mean within and between NPA-proximities}

\begin{tabular}{|l|l|}
\hline Company & $\begin{array}{l}\text { Within-firm announcement mean } \\
\text { proximity }(d \text { mean })\end{array}$ \\
\hline 1 Samsung & $2.52(n=55)$ \\
\hline 2 Micron & $2.21 \quad(n=78)$ \\
\hline 3 Hyundai & $2.03(n=28)$ \\
\hline 4 NEC & $2.15(n=15)$ \\
\hline 5 Toshiba & $2.30(n=10)$ \\
\hline 6 Infineon & $2.27 \quad(n=6)$ \\
\hline 7 Hitachi & $1.47 \quad(n=15)$ \\
\hline 8 Mitsubishi & $2.16 \quad(n=3)$ \\
\hline 9 Mosel Vitelic & $2.47(n=6)$ \\
\hline 10 Fujitsu & $1.85(n=6)$ \\
\hline \hline Overall d mean & \\
\hline $\begin{array}{l}\text { (firm-internal and } \\
\text { firm-external) }\end{array}$ & $2.48(n=2016)$ \\
\hline
\end{tabular}


Table 4: NPA content attributes per strategy type

\begin{tabular}{|c|c|c|c|c|}
\hline & Attributes & $\begin{array}{l}\text { Percentage of } \\
\text { NPAs in which } \\
\text { attribute appears } \\
\text { for strategy type } \\
\text { Leader }\end{array}$ & $\begin{array}{l}\text { Percentage of } \\
\text { NPAs in which } \\
\text { attribute appears } \\
\text { for strategy type } \\
\text { Challenger }\end{array}$ & $\begin{array}{l}\text { Percentage of } \\
\text { NPAs in which } \\
\text { attribute appears } \\
\text { for strategy type } \\
\text { Follower }\end{array}$ \\
\hline \multirow[t]{7}{*}{ Product } & Power & 73 & 86 & 63 \\
\hline & Speed & 64 & 81 & 50 \\
\hline & Compatibility & 27 & 48 & 53 \\
\hline & Performance & 36 & 76 & 28 \\
\hline & Memory & 45 & 29 & 31 \\
\hline & Size & 55 & 10 & 38 \\
\hline & Standardsetting & 18 & 14 & 6 \\
\hline \multirow[t]{2}{*}{ Price } & Specific price & 0 & 62 & 50 \\
\hline & $\begin{array}{l}\text { Price } \\
\text { competitiveness }\end{array}$ & 64 & 57 & 25 \\
\hline \multirow[t]{3}{*}{ Promotion } & Promotion & 0 & 0 & 0 \\
\hline & $\begin{array}{l}\text { Spokesperson in } \\
\text { NPA }\end{array}$ & 45 & 100 & 38 \\
\hline & $\begin{array}{l}\text { Endorsement in } \\
\text { NPA }\end{array}$ & 9 & 38 & 19 \\
\hline \multirow[t]{3}{*}{ Distribution } & Distribution & 0 & 0 & 0 \\
\hline & $\begin{array}{l}\text { Time to market } \\
\text { (sampling) }\end{array}$ & 45 & 86 & 84 \\
\hline & $\begin{array}{l}\text { Time to market } \\
\text { (mass volume) }\end{array}$ & 55 & 62 & 56 \\
\hline \multirow[t]{2}{*}{ Market } & Market growth & 82 & 10 & 13 \\
\hline & $\begin{array}{l}\text { Intended market } \\
\text { position }\end{array}$ & 55 & 14 & 6 \\
\hline
\end{tabular}


Table 5: NPA content in relation to strategic stance of the announcing firm

\begin{tabular}{|c|c|c|}
\hline Leader & Challenger & Follower \\
\hline $\begin{array}{l}\text { Emphasizes product } \\
\text { characteristics speed and power } \\
\text { while also pointing to capabilities } \\
\text { in terms of size and memory } \\
\text { capacities. Never mentions } \\
\text { specific product prices but does } \\
\text { stress that prices will be } \\
\text { competitive. Promotion and } \\
\text { distribution receive little attention } \\
\text { in the NPAs. The market leader } \\
\text { stresses the capabilities of } \\
\text { market growth and its own strong } \\
\text { position in the growing market. }\end{array}$ & $\begin{array}{l}\text { Emphasizes power, speed and } \\
\text { performance as important } \\
\text { product characteristics. Price and } \\
\text { price competitiveness are } \\
\text { mentioned prominently. } \\
\text { Promotion and distribution are } \\
\text { given less attention, though not } \\
\text { disregarded. Market growth } \\
\text { prospects and market position } \\
\text { are hardly mentioned. }\end{array}$ & $\begin{array}{l}\text { Emphasizes power, speed and } \\
\text { compatibility as important } \\
\text { product characteristics. Price is } \\
\text { mentioned in half of the } \\
\text { announcements. Promotion, } \\
\text { distribution and market receive } \\
\text { relatively little attention. }\end{array}$ \\
\hline
\end{tabular}




\section{Publications in the Report Series Research* in Management}

ERIM Research Program: "Marketing"

\section{3}

The Effect of Members' Satisfaction with a Virtual Community on Member Participation Fred Langerak, Peter C. Verhoef, Peeter W.J. Verlegh, Kristine de Valck ERS-2003-004-MKT

http://hdl.handle.net/1765/269

Surprise ... Surprise, An Empirical Investigation on How Surprise is Connected to Customer Satisfaction Joëlle Vanhamme

ERS-2003-005-MKT

http://hdl.handle.net/1765/273

Differentiated Bayesian Conjoint Choice Designs

Zsolt Sándor, Michel Wedel

ERS-2003-016-MKT

http://hdl.handle.net/1765/320

A Multi-Country Study Of The Adoption Of ERP Systems: The Effect Of National Culture Yvonne M. van Everdingen, Eric Waarts ERS-2003-019-MKT

http://hdl.handle.net/1765/280

New Product Announcements As Market Signals; A Content Analysis In The DRAM Chip Industry Wybe T. Popma, Eric Waarts, Berend Wierenga ERS-2003-025-MKT

http://hdl.handle.net/1765/328

Estimating Duration Intervals

Philip Hans Franses, Björn Vroomen

ERS-2003-031-MKT

On The Bass Diffusion Theory, Empirical Models And Out-Of-Sample Forecasting

Philip Hans Franses

ERS-2003-034-MKT

Predicting Customer Lifetime Value in Multi-Service Industries

Bas Donkers, Peter C. Verhoef, Martijn de Jong

ERS-2003-038-MKT

http://hdl.handle.net/1765/325

Confidence Intervals for Cronbach's Coefficient Alpha

Alex J. Koning, Philip Hans Franses

ERS-2003-041-MKT

* A complete overview of the ERIM Report Series Research in Management: http://www.erim.eur.nl

ERIM Research Programs:

LIS Business Processes, Logistics and Information Systems

ORG Organizing for Performance

MKT Marketing

F\&A Finance and Accounting

STR Strategy and Entrepreneurship 
Modeling Dynamic Effects of the Marketing Mix on Market Shares

Dennis Fok, Richard Paap, Philip Hans Franses

ERS-2003-044-MKT 